\title{
Rescue of Locomotor Impairment in Dopamine D2 Receptor- Deficient Mice by an Adenosine A2A Receptor Antagonist
}

\author{
Shiro Aoyama, ${ }^{1,2}$ Hiroshi Kase, ${ }^{2}$ and Emiliana Borrelli ${ }^{1}$ \\ 1/nstitut de Génétique et de Biologie Moléculaire et Cellulaire, BP163, 67404 IIIkirch Cedex, C.U. de Strasbourg, France, \\ and 2Pharmaceutical Research Institute, Kyowa Hakko Kogyo Co., Ltd., Nagaizumi-cho Shizuoka, 411-8731 Japan
}

In Parkinson's disease a degeneration of dopaminergic neurons of the nigrostriatal pathway is observed. Loss of dopaminergic regulation of striatal neuron activity results in altered motor functions. Adenosine A2A (A2AR) and dopamine D2 (D2R) receptors are colocalized in striatal medium spiny neurons. It has been proposed that adenosine binding to A2AR lowers the affinity of dopamine for D2R, thus modulating the function of this receptor. Absence of D2R in knockout mice (D2R-/-) results in impaired locomotion and coordinated movements. This indicates that absence of dopamine in Parkinson's disease might principally affect D2R-mediated effects with regard to locomotor functions. A2ARselective antagonists have been demonstrated to have antiparkinsonian activities in various models of Parkinson's disease in rodents and nonhuman primates. In this article, D2R-/- mice were used to explore the possibility that an A2AR antagonist might reestablish their motor impairment. Interestingly, blockade of A2AR rescues the behavioral parameters altered in D2R-/mice. In addition, the level of expression of enkephalin and substance $\mathrm{P}$, which were altered in $\mathrm{D} 2 \mathrm{R}-/-$, were also reestablished to normal levels after A2AR antagonist treatment. These results show that $A 2 A R$ and $D 2 R$ have antagonistic and independent activities in controlling neuronal and motor functions in the basal ganglia. They also provide evidence that selective A2AR antagonists can exhibit their anti-parkinsonian activities through a nondopaminergic mechanism.

Key words: adenosine A2 receptor; dopamine D2 receptor; striatum; KW-6002; Parkinson's disease; knockout mice
Parkinson's disease affects the major component of the basal ganglia, the striatum, $90 \%$ of which is composed of GABA-releasing medium-sized spiny neurons. These neurons receive dopaminergic afferent fibers from the substantia nigra as well as massive glutamatergic cortical afferences. They generate the striatopallidal, or indirect, and striatonigral, or direct, pathways. The direct pathway relieves inhibition of thalamocortical neurons and facilitates desired movements, whereas the indirect pathway causes inhibition of these neurons and inhibits undesired movements. Dopamine depletion in Parkinson's disease causes an increased function of the striatopallidal neurons, leading to an unbalanced activity of these pathways (DeLong, 1990; Obeso et al., 1997).

A recently developed adenosine A2AR selective antagonist, (E)-1,3-diethyl-8-(3,4-dimethoxystyryl)-7-methyl-3,7-dihydro-1Hpurine-2,6-dione (KW-6002) exhibits anti-parkinsonian activities in rodent as well as in nonhuman primate models of the disease (Shimada et al., 1997, Shiozaki et al., 1999, Kanda et al., 1998). Adenosine A2A receptors (A2ARs) are localized at high density in the basal ganglia (Jarvis and Williams, 1989), where they seem to influence motor behavior (Ferré et al., 1991a; Nikodijevic et al., 1991; Richardson et al., 1997). In particular, A2ARs are predominantly expressed in striatopallidal neurons that also express dopamine D2 receptors (D2Rs) (Fink et al., 1992). The mechanism by which adenosine affects motor functions has been thought to be attributable to modulation of dopamine-mediated signaling. It is presently unclear whether adenosine has an independent role in the control of locomotion. Interactions between A2AR and D2R activities have been shown at the plasma membrane and intracellular levels. A2AR stimulation affects the affinity of dopamine for D2R (Ferré et al., 1991b), counteracts D2R-mediated $\mathrm{Ca}^{2+}$ influx (Yang

\footnotetext{
Received April 5, 2000; revised May 8, 2000; accepted May 9, 2000.

This work was supported by grants from Kyowa Hakko Kogyo, Co., Ltd., Centre National de la Recherche Scientifique, Institut National de la Santé et de la Recherche Médicale, MILDT, and ARC to E.B. We thank M. Kobayashi and N. Foulkes for discussions.

Correspondence should be addressed to Dr. Emiliana Borrelli, Institut de Génétique et de Biologie Moléculaire et Cellulaire, BP163, 67404 Illkirch Cedex, C.U. de Strasbourg, France. E-mail: eb@igbmc.u-strasbg.fr.

Copyright (C) 2000 Society for Neuroscience $0270-6474 / 00 / 205848-05 \$ 15.00 / 0$
}

et al., 1995), and abolishes the D2R-mediated tonic inhibition of c-fos expression (Boegman and Vincent, 1996). Thus, it has been proposed that $A 2 A R-D 2 R$ interactions may constitute the main molecular mechanism underlying many of the observed effects of adenosine agonists and antagonists (Ferré et al., 1997). However, increasing evidence suggests that A2ARs can operate independently from D2Rs by modulating GABA release and recurrent feedback inhibition of striatal neurons (Kurokawa et al., 1994; Mori et al., 1996). This illustrates a potential key function of adenosine in the control of movements (Richardson et al., 1997).

D2R knockout mice (D2R-/-) (Baik et al., 1995; Kelly et al., 1998; Jung et al., 1999) thus provide a tool to evaluate the role of $\mathrm{A} 2 \mathrm{AR}$ in motor control as related to dopamine receptor function. $\mathrm{D} 2 \mathrm{R}-/-$ mice present a locomotor phenotype with analogies to Parkinson's disease (Baik et al., 1995). In these mice we evaluated the effect of KW-6002 treatments on the rescue of their locomotor abnormalities as well as on striatal neuropeptide gene expression as an indicator of $\mathrm{D} 2 \mathrm{R}-/-$ mice neuronal activity. The results indicate that blockade of A2AR is able to rescue the locomotor deficits of $\mathrm{D} 2 \mathrm{R}-/-$ mice probably by modulating striatal projection neuron activities, even in the absence of D2R. These results show a dopamine-independent role for adenosine in the control of motor functions through A2AR in the striatum. They also illustrate a novel non-D2R-dependent mechanism for the anti-parkinsonian activities of selective A2AR antagonists.

\section{MATERIALS AND METHODS}

Mice. D2R-/- mice (Baik et al., 1995) had a mixed 129SV/C57BL/6 genetic background, with a $75 \%$ contribution of C57BL/6. Genotypes of mice were confirmed by genomic Southern hybridization analyses. Mice were group-caged and maintained in a light-controlled room (12 hr light/ dark cycle) under standard animal housing conditions. Experiments were performed in conformity with the French publication on animal experimentation (no. 87-848).

Drug treatment and behavioral tests. KW-6002 was synthesized at the Medicinal Chemistry Department of the Pharmaceutical Research Institute (Shizuoka, Japan). The behavioral experiments were performed between 2 and 8 P.M. Wild-type (WT) and D2R-/- littermates were administered $2.5 \mathrm{mg} / \mathrm{kg} \mathrm{KW}-6002$ (suspension in $0.3 \%$ Tween 80,10 $\mathrm{ml} / \mathrm{kg}$, p.o.) or vehicle $(0.3 \%$ Tween 80$)$. Locomotor activity was measured in a Plexiglas cage $(30 \times 50 \times 15 \mathrm{~cm})$, the floor of which was partitioned into 12 squares of equal surface area (Janssen et al., 1960). Mice were 

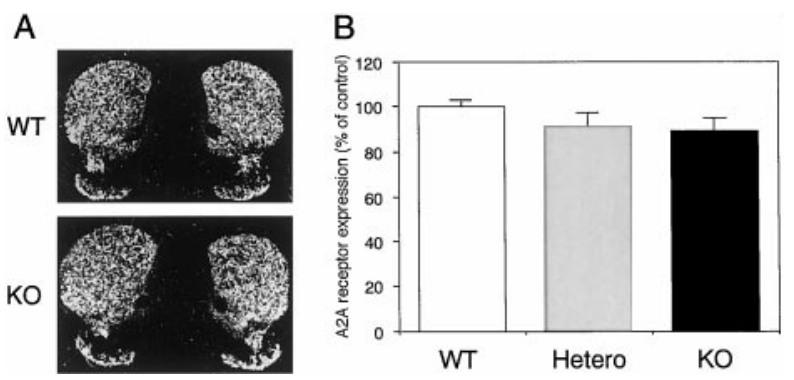

Figure 1. Expression of adenosine A2AR mRNA in striatum of WT, heterozygote, and $\mathrm{D} 2 \mathrm{R}-1-$ mice. $A, B$, Adenosine A2AR in situ hybridizations on coronal sections from WT and D2R-/- mice $(K O)$. $C$, Northern blot analysis of A2AR expression in striata from WT, heterozygote $\mathrm{D} 2 \mathrm{R}+/-($ Hetero $)$, and $\mathrm{D} 2 \mathrm{R}-/-(K O)$ mice. Values are presented as percentage of WT control.

placed in the cages and left $1 \mathrm{hr}$ for habituation, then administered the drug $(n=6$, WT; $n=7, \mathrm{D} 2 \mathrm{R}-1-)$ or vehicle $(n=6$, WT; $n=8, \mathrm{D} 2 \mathrm{R}-/-)$ and returned to the cage. The behavior of the mice was recorded by video camera for $5 \mathrm{~min}$ each $15 \mathrm{~min}$ during a $120 \mathrm{~min}$ session. For the rotarod test (Wolffgramm et al., 1990), each mouse was placed on a 3.5-cm-diameter rod covered with rubber $2.5 \mathrm{hr}$ after drug $(n=6$, WT; $n=9, \mathrm{D} 2 \mathrm{R}-/-)$ or vehicle $(n=12$, WT; $n=9, \mathrm{D} 2 \mathrm{R}-/-)$ treatment. Animals were left for 1 min on the rod to habituate. The rod rotated at eight turns per minute, and the behavior of mice was scored for a maximum of $3 \mathrm{~min}$. The best performance among three trials was used for analysis. For the ring test (Pertwee, 1972), each mouse was placed on a 5.5-cm-diameter ring attached to a stand $16 \mathrm{~cm}$ above the base $2.5 \mathrm{hr}$ after treatment with drug $(n=6, \mathrm{WT} ; n=9, \mathrm{D} 2 \mathrm{R}-/-)$ or vehicle $(n=18$, WT; $n=9, \mathrm{D} 2 \mathrm{R}-/-)$ treatment, and the behavior was video-recorded for $5 \mathrm{~min}$. The length of the period without any voluntary movements was measured.

Radioligand binding assay. Striata from WT or D2R $-1-$ mice were homogenized in $10 \mathrm{vol}$ of ice-cold $10 \mathrm{~mm}$ Tris- $\mathrm{HCl}, \mathrm{pH} 7.5,5 \mathrm{~mm}$ EDTA with a Polytron homogenizer $(13,500 \mathrm{rpm}, 30 \mathrm{sec})$. The homogenate was centrifuged at $1,000 \times g$ for $10 \mathrm{~min}$ at $4^{\circ} \mathrm{C}$. The pellet was resuspended in buffer and centrifuged at the same speed. The supernatant was recovered and centrifuged at $45,000 \times g$ for $45 \mathrm{~min}$ at $4^{\circ} \mathrm{C}$, and the resultant pellet was resuspended in $50 \mathrm{~mm}$ Tris- $\mathrm{HCl}, \mathrm{pH} \mathrm{7.7}$, and stored in aliquots at $-80^{\circ} \mathrm{C}$. [ ${ }^{3} \mathrm{H}$ ]CGS21680 binding was performed in $50 \mathrm{~mm}$ Tris- $\mathrm{HCl}, \mathrm{pH} 7.7$ $10 \mathrm{mM} \mathrm{MgCl}_{2}$, and $0.1 \mathrm{U} / \mathrm{ml}$ adenosine deaminase. Striatal membranes $(50$ $\mu \mathrm{g}$ ) were incubated in this buffer in the presence of increasing concentrations of $\left[{ }^{3} \mathrm{H}\right] \mathrm{CGS} 21680$ (DuPont NEN, Belgium) ranging from 0.5 to 40 $\mathrm{nM}$ for $60 \mathrm{~min}$ at $25^{\circ} \mathrm{C}$. Nonspecific binding was determined in the presence of $30 \mathrm{~mm}$ R-PIA. Incubations were stopped by rapid filtration at $0-4^{\circ} \mathrm{C}$ through Whatman GF/B filters using a Brandel cell harvester, followed by three washes with $2 \mathrm{ml}$ of ice-cold $50 \mathrm{~mm}$ Tris-HCl, $\mathrm{pH}$ 7.7. Binding data were analyzed with the EBDA-LIGAND program (Munson and Rodbard, $1980)$ using the one-site fitting model, allowing the determination of dissociation constant $\left(K_{\mathrm{d}}\right)$ and maximal binding capacity $\left(B_{\mathrm{max}}\right)$ values for each experiment. Protein concentration were determined with a protein assay kit (Bio-Rad, Richmond, CA).

RNA analyses. Mouse Substance P (SP) and A2AR probes were synthesized from cDNAs obtained by RT-PCR from mouse striatal RNA and cloned into pBlueScript (Stratagene, La Jolla, CA). Oligonucleotide primers used are as follows: for SP, 5'-AAGGAGAGCAAAGAGCGCCCA-3' and 5'-CAGCATCCCGCTTGCCCATT-3', which amplify a fragment from nucleotide (nt) 29 to 319 of the mouse $\beta$-preprotachykinin A (D17584); for A2AR, 5'-CGCCATCCGAATTCCACTCC-3' and 5'CGGAACTCCCGGATCCTGTA-3', which amplify a fragment of the mouse A2AR (U05672) from nt 542 to 1109 . A mouse enkephalin probe was synthesized from a $P v u \mathrm{II}-\mathrm{Xba}$ I cDNA fragment of $762 \mathrm{bp}$ (Zurawski et al., 1986)

Total RNA was prepared from striatum of WT or knockout mice by the guanidinium-thiocyanate method (Chomczynski and Sacchi, 1987). Five micrograms of total RNA were separated in formaldehyde/agarose gels and transferred to Hybond N+ (Amersham, Arlington Heights, IL). $\beta$-actin was used as an internal standard for RNA quantification. Signals were quantified with a Fuji Bio-Imaging analyzer BAS 2000 (Fuji Film, Tokyo, Japan).

RNase protection analyses were performed as described previously (Sambrook et al., 1989). Four animals of each genotype and treatment were analyzed in three independent experiments. Two micrograms of total RNA from striatum were hybridized overnight at $45^{\circ} \mathrm{C}$ with a molar excess of ${ }^{32} \mathrm{P}$-labeled mouse enkephalin, $\mathrm{SP}$, and $\mathrm{H} 4$ histone or $\beta$-actin riboprobes. Hybridized samples were treated with RNase A $(40 \mathrm{mg} / \mathrm{ml})$ and $\mathrm{T}_{1}$ $(2 \mathrm{mg} / \mathrm{ml})$, then with Proteinase $\mathrm{K}(150 \mathrm{mg} / \mathrm{ml})$. Protected fragments were run on a $6 \%$ polyacrylamide $/ 8 \mathrm{M}$ urea gel. Autoradiograms were quantified with an Imaging densitometer (Bio-Rad GS-700). H4 histone or $\beta$-actin was used as an internal standard control for quantification. Data were analyzed by two-tailed unpaired $t$ test.

In situ hybridization. Mice were killed by cervical dislocation. Brains

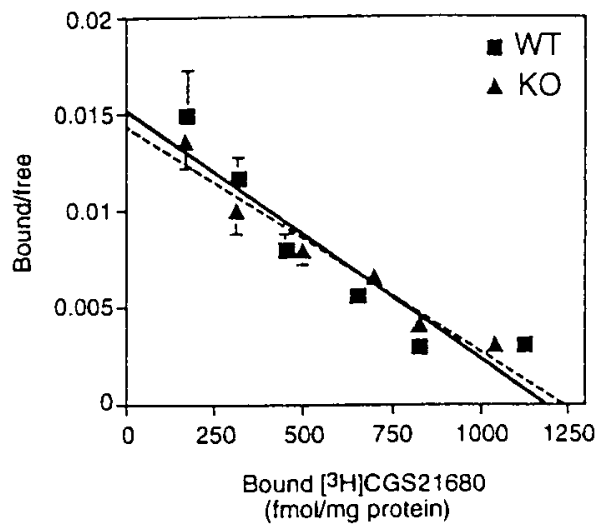

Figure 2. Binding of $\left[{ }^{3} \mathrm{H}\right] \mathrm{CGS} 21680$ to mouse striatal membranes. Scatchard analysis of the saturation binding experiment using $\left[{ }^{3} \mathrm{H}\right] \mathrm{CGS} 21680$ in WT $(\mathbf{\square})$ and D2R $-/-(\boldsymbol{\Delta})$ mice. Maximum binding capacities $\left(B_{\max }\right)$ in $\mathrm{fmol} / \mathrm{mg}$ protein $=1175 \pm 141.4$ for WT; $1233 \pm 37.4$ for D2R $-/-$; dissociation constant $\left(\mathrm{K}_{d}\right)$ in $\mathrm{nM}=6.5 \pm 0.6$ for $\mathrm{WT} ; 7.5 \pm 0.6$ for $\mathrm{D} 2 \mathrm{R}-/-$. Values are mean \pm SEM of four independent experiments performed in duplicate.

were removed rapidly, frozen on dry ice, and sectioned $(10 \mu \mathrm{m})$ on a cryostat. For hybridization, antisense and sense RNA probes were labeled with $\left[\alpha^{35}\right.$ S]CTP $(>800 \mathrm{Ci} / \mathrm{mmol}$; Amersham) by standard conditions using $\mathrm{T}_{3}$ or $\mathrm{T}_{7}$ polymerases (Promega, Madison, WI). In situ hybridization was performed as described previously (Baik et al., 1995). The specificity of the hybridization was confirmed by the use of sense riboprobes, which showed no detectable signals.

Statistics. Differences between D2R-/- and WT in behavioral tests were conducted with independent $t$ tests or repeated measures two-way ANOVA for genotype and drug treatment interaction determinations. Individual comparisons were conducted with Student's $t$ test.

\section{RESULTS}

\section{A2AR receptor expression is unaffected in D2 receptor knockout mice}

A2AR and D2R are coexpressed in striatal medium spiny neurons. These two receptors are oppositely coupled to the cAMP signaling pathway (Van Calker et al., 1979). It has been shown that the activation of A2AR affects the affinity of dopamine for D2R (Ferré et al., 1991b). Chronic treatment with haloperidol, a D2R antagonist, increases intramembrane interactions between A2AR and D2R (Ferré et al., 1994). Thus, we investigated whether absence of D2Rs in mutant mice has some influence on the expression and the pharmacological characteristics of A2AR.

No alterations in the distribution and level of expression of the
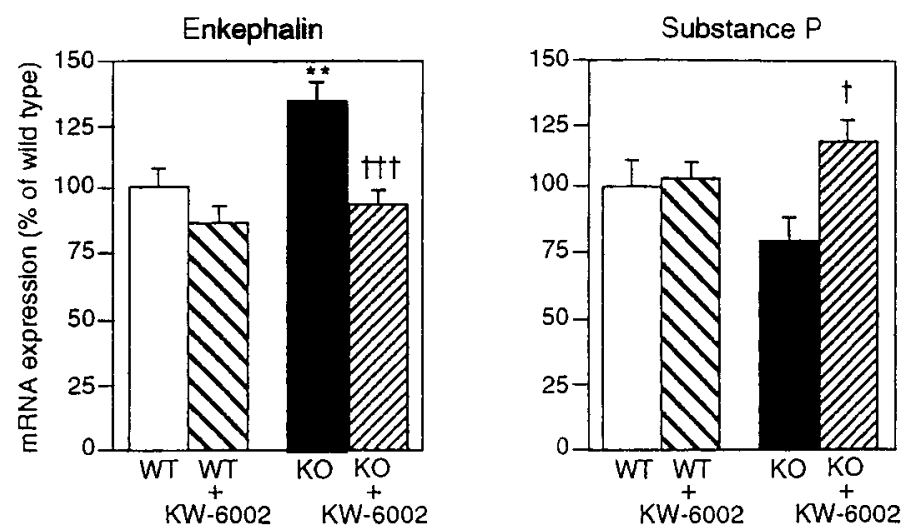

Figure 3. Effect of KW-6002 treatment on striatal neuropeptide expressions. D2R $-/-$ and WT mice were treated with $\mathrm{KW}-6002(2.5 \mathrm{mg} / \mathrm{kg})$ or vehicle. Mice were killed $3 \mathrm{hr}$ after treatment. Neuropeptide mRNA expression levels in each treatment are expressed as percentage of control (WT treated with vehicle) \pm SEM from $4-11$ individuals in each group. $* *$, $p<0.01$ versus wild type with vehicle treatment. ${ }^{\dagger}, p<0.05 ;{ }^{\dagger \dagger}, p<0.001$ versus D2R $-/-$ mice with vehicle treatment by Student's $t$ test. 
A

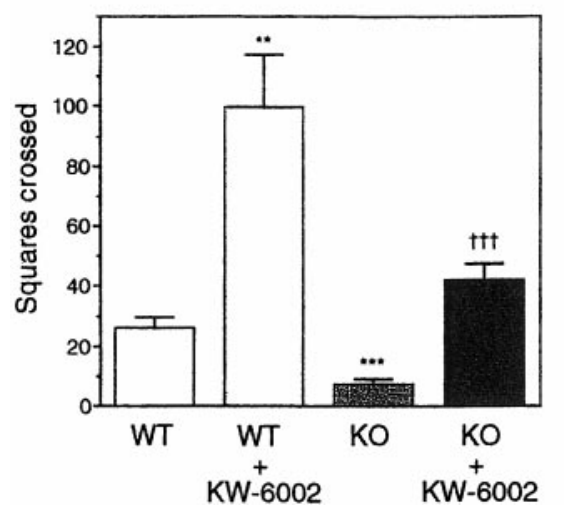

B

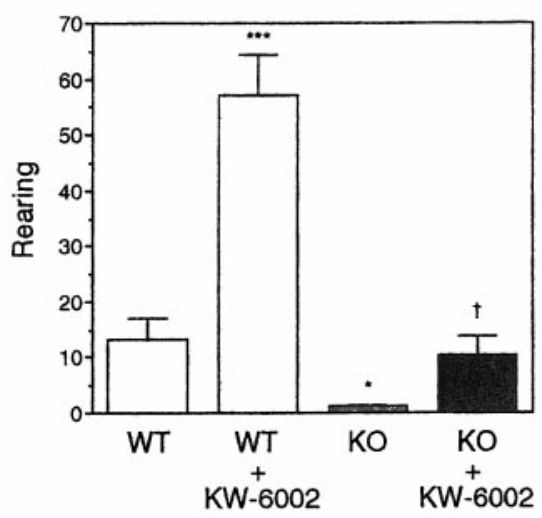

Figure 4. Effect of KW-6002 on locomotor activities of $\mathrm{WT}$ and $\mathrm{D} 2 \mathrm{R}-/-$ mice. Horizontal $(A)$ and vertical (B) movement of $\mathrm{WT}$ and $\mathrm{D} 2 \mathrm{R}-/-$ mice in $10 \mathrm{~min}$. After $1 \mathrm{hr}$ habituation, mice were administered vehicle or KW-6002 $(2.5 \mathrm{mg} / \mathrm{kg})$, and their locomotor activities were counted for $5 \mathrm{~min}$. Values represent sum of $5 \mathrm{~min}$ counting at 0 and 15 min after administration. ${ }^{*}, p<$ $0.05, * *, p<0.01, * * *, p<0.001$ versus WT vehicletreated, ${ }^{\dagger}, p<0.05,{ }^{\dagger \dagger}, p<0.001$ versus vehicle-treated $\mathrm{D} 2 \mathrm{R}-/-$ mice; Student's $t$ test.
A2AR mRNA in D2R - /- mice were found as compared with WT littermates (Fig. 1 $A, B$ ).

To pharmacologically characterize A2ARs in $\mathrm{D} 2 \mathrm{R}-/-$ mice, ligand binding experiments were performed using the A2AR agonist $\left[{ }^{3} \mathrm{H}\right] \mathrm{CGS} 21680$ on striatal membranes. No significant differences in the affinity and density of $\left[{ }^{3} \mathrm{H}\right] \mathrm{CGS} 21680$ binding sites were found (WT mice: $K_{\mathrm{d}} 6.5 \pm 0.6 \mathrm{~nm}$ and $B_{\max } 1175 \pm 141.3$ $\mathrm{fmol} / \mathrm{mg}$ protein; D2R-/- mice: $K_{\mathrm{d}} 7.5 \pm 0.5 \mathrm{~nm}$ and $B_{\max } 1233 \pm$ $37.3 \mathrm{fmol} / \mathrm{mg}$ protein) (Fig. 2). Thus, neither the expression nor the pharmacological properties of A2ARs are affected by the loss of $\mathrm{D} 2 \mathrm{R}$ expression in vivo.

\section{$\mathrm{KW}-6002$ is able to reverse altered neuropeptide levels in D2R-/- mice}

D2R - / - mice exhibit altered gene expression of striatal neuropeptides, such as enkephalin and substance P (Baik et al., 1995), which reflects alteration of the activities in the striatopallidal and striatonigral neurons, respectively. Enkephalin is coexpressed with D2R and A2ARs in the striatopallidal neurons, whereas SP and dynorphin colocalize with D1R in striatonigral neurons (Gerfen et al., 1990).

Comparative studies on the expression of these genes were performed on total RNA extracted from the striatum of D2R-/and WT mice after treatment with KW-6002 or saline. In agreement with previous studies (Baik et al., 1995), a 32\% increase in enkephalin mRNA expression and a $23 \%$ decrease in SP mRNA were observed in $\mathrm{D} 2 \mathrm{R}-/-$ mice as compared with WT animals (Fig. 3). Interestingly, KW-6002 administration $(2.5 \mathrm{mg} / \mathrm{kg})$ in the mutants decreased enkephalin expression (93\% of WT, $n=7$ ) (Fig. 3) and increased SP expression (118\% of WT, $n=5$ ) (Fig. 3) to normal WT levels.

Thus KW-6002 is able to reverse the altered neuropeptide's expression caused by the loss of D2R signaling, indicating that the

Table 1. Total locomotor activity in the open field

\begin{tabular}{|c|c|c|c|c|c|c|}
\hline & \multicolumn{3}{|l|}{ Wild type } & \multicolumn{3}{|c|}{ D2R knockout } \\
\hline & Mean & & SEM & Mean & & SEM \\
\hline \multicolumn{7}{|l|}{ Ambulation } \\
\hline Vehicle & 29.3 & \pm & 5.1 & $13.8 \dagger$ & \pm & 4.2 \\
\hline KW-6002 & $728.8^{* * *}$ & \pm & 88.9 & $251.7^{* *}$ & \pm & 44.5 \\
\hline \multicolumn{7}{|l|}{ Rearing } \\
\hline Vehicle & 17.1 & \pm & 5.0 & $2.5 \dagger$ & \pm & 1.3 \\
\hline KW-6002 & $387.0 * * *$ & \pm & 26.5 & $77.7^{* *}$ & \pm & 18.7 \\
\hline
\end{tabular}

Total counts of crossed squares (ambulation) or rearings scored for 5 min every $15 \mathrm{~min}$ during a 2 hr session. Values represent mean \pm SEM. ${ }^{*}, p<0.05,{ }^{* * *}, p<0.001$ versus WT with vehicle treatment; $\dagger \dagger, p<0.01$ versus knockout with vehicle treatment, by Student's $t$ test. $n=6$ for WT for each treatment, and $n=8 \mathrm{D} 2 \mathrm{R}-/-$ for vehicle and $n=7 \mathrm{D} 2 \mathrm{R}-/-$ for $\mathrm{KW}-6002$ treatment. blockade of adenosine A2AR normalizes the unbalanced neuronal activities of striatal output pathways.

\section{$\mathrm{KW}-6002$ rescues motor activity in D2R-/- mice}

$\mathrm{D} 2 \mathrm{R}-/-$ mice have impaired locomotion characterized by a reduction of spontaneous movements and stereotypies. If normalization of imbalanced activity of striatal neurons on KW6002 treatment occurs in D2R $-/-$ mice, this should also lead to an amelioration of their motor impairment. Thus, behavioral tests originally used to characterize D2R $-/-$ mice (open field, rotarod, and ring test) were performed.

Animals from both genotypes were habituated to the open field before being orally administered KW-6002 or vehicle (Fig. 4A). Mice were then administered either KW-6002 or saline, and the number of crossed squares and rearings were counted for the next $2 \mathrm{hr}$ (Table 1). KW-6002 produced a similar significant increase in ambulation in both genotypes (WT, $p=0.0005$; D2R $-/-, p=$ 0.0017 ) and rearings (WT, $p=0.0001 ; \mathrm{D} 2 \mathrm{R}-/-, p=0.004$ ) (Fig. $4 A, B$, Table 1$)$. These effects lasted during the $2 \mathrm{hr}$ of the test. A two-way ANOVA grouped on genotype and treatment showed a significant interaction between genotype and treatment (ambulation, $F_{(1,23)}=25.3$; rearing, $\left.F_{(1,23)}=80.9\right)$. However, a similar percentage increase in ambulation and rearings was observed in the two genotypes with respect to their basal level of locomotion (Table 1). These results indicate that KW6002 induces hyperactivity in the WT as well as in the knockouts, demonstrating a D2Rindependent function for the A2AR. Furthermore, this compound is able to completely rescue the locomotor impairment of D2R-/mice to saline-treated WT levels.

Coordination of movements was tested using the rotarod apparatus. D2R $-/-$ mice are not able to correctly perform this test (Baik et al., 1995), and they spent significantly shorter time on the rotating rod than WT littermates $(p=0.017)$ (Fig. $5 A)$. Importantly, KW-6002 restored D2R - / - mice performance and prolonged the time spent on the rod in both genotypes $(p=0.0005$ for $\mathrm{WT}, p=0.0075$ for D2R-/-) (Fig. 5A). ANOVA grouped on genotype and treatment showed that there was no genotypetreatment interaction $\left(F_{(1,32)}=0.8, p=0.38\right)$.

Spontaneous movements that were quantified using the ring test showed fewer voluntary movements in D2R $-/-$ than in WT mice (Fig. 5B) $(p<0.0001)$. KW-6002 increased voluntary movements in both genotypes, shortening the time spent being immobile (Fig. $5 B)(p=0.0021$ for WT; $p<0.0001$ for D2R-/-). Genotypetreatment interaction was found $\left(F_{(1,38)}=18.6\right)$. Taken together, these results indicate that $\mathrm{KW}-6002$ can rescue the movement impairment elicited by ablation of D2Rs.

\section{DISCUSSION}

$\mathrm{D} 2 \mathrm{R}-/-$ mice present an impairment of locomotor functions, indicating a preponderant role for D2R in the control of locomotion (Baik et al., 1995; Kelly et al., 1998; Jung et al., 1999). D2Rs are 
A

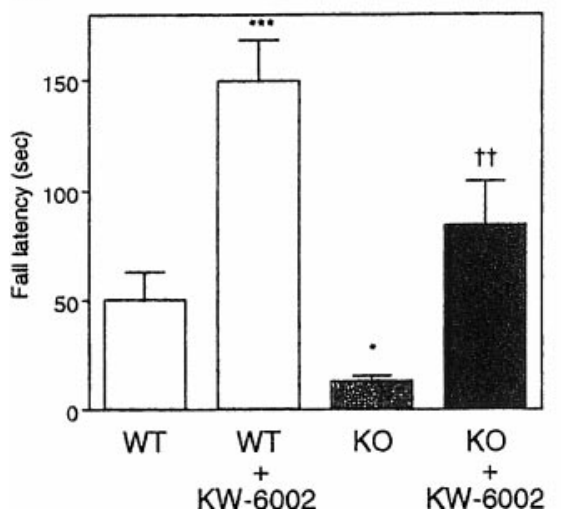

B

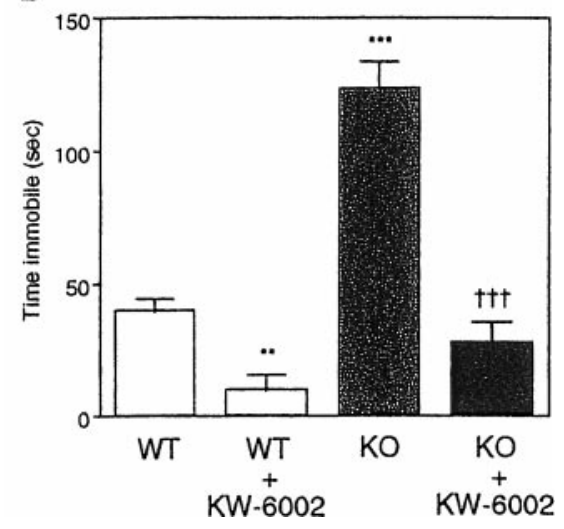

Figure 5. Effects of KW-6002 on coordinate and spontaneous movements. Rotarod $(A)$ and ring $(B)$ tests were conducted $2.5 \mathrm{hr}$ after administration with vehicle or KW-6002. The rod was rotated at eight turns per minute for a maximum of $3 \mathrm{~min}$. The time that mice spent on the rod without falling down was measured, and the best performance among three trials was used for analysis. For the ring test, the duration ot time that mice did not show any voluntary movements on a 5.5$\mathrm{cm}$-diameter ring was measured. Values represent mean \pm SEM fall latency or time immobile (in seconds). $*, p<0.05, * *, p<0.01$, ***, $p<0.001$ versus $\mathrm{WT}$ vehicle-treated mice. ${ }^{\dagger}, p<0.01,{ }^{\dagger \dagger}, p<0.001$ versus vehicle treated D2R $-1-$ mice by Student's $t$ test. colocalized with A2ARs in the striatal medium spiny neurons. A2AR-mediated signaling may be involved in the control of motor functions (Ferré et al., 1992). New highly selective A2AR antagonists have been demonstrated to exert anti-parkinsonian activities in MPTP-treated rodents and primates (Kanda et al., 1998; Shiozaki et al., 1999). D2Rs and A2ARs have opposite effects on the cAMP transduction pathway, which might have contrasting effects on biochemical and behavioral parameters (Ferré et al., 1997). We thus investigated whether blockade of the A2AR in D2R $-/-$ mice might reestablish some of the motor and biochemical deficits found in these mice, via the regulation of neuronal activities in striatal neurons.

mRNA and binding properties of the A2AR are unmodified in D2R $-/-$ mice (Figs. 1, 2). Thus, the absence of D2R does not result in a compensatory modification of the expression level and binding characteristics of A2AR. This is consistent with previous reports showing that the number of A2AR binding sites is not altered by deficits in dopaminergic transmission (Morelli et al., 1994; Przedborski et al., 1995) as well as in Parkinson's disease (Martinez-Mir et al., 1991). This implies that there might not be direct membrane interactions between A2AR and D2Rs, as has been postulated (Ferré et al., 1992, 1997).

It has been demonstrated previously that dopamine depletion, D2R blockade by antagonists, and D2R gene knockout results in an increase in the expression of the preproenkephalin gene (Augood et al., 1989; Baik et al., 1995; Richardson et al., 1997). Conversely, the knockout of the A2AR (Ledent et al., 1997) as well as antagonist blockade (Richardson et al., 1997) of this receptor leads to a decrease of preproenkephalin expression in the striatum. In agreement with this, our results demonstrate that $\mathrm{KW}-6002$ is able to reverse the alterations observed in enkephalin and SP expression caused by the absence of D2R. These results clearly establish a relevant and antagonistic physiological control exerted by A2AR and D2R on enkephalin expression, which is coexpressed in the same neurons. These results support an independent function in vivo of these two receptors, which is compatible with electrophysiological data showing that presynaptic A2ARs activate striatopallidal neurons by counteracting striatopallidal GABAergic neurotransmission (Kurokawa et al., 1994; Mori et al., 1996).

Interestingly, in $\mathrm{D} 2 \mathrm{R}-/-$ and $\mathrm{A} 2 \mathrm{AR}-/-$ mice, a reduction of SP expression has been observed (Baik et al., 1995; Ledent et al., 1997) despite the proposed localization of these receptors and SP in different neurons (Le Moine et al., 1991; Schiffmann et al., 1991). Immunohistochemical evidence has shown that the spiny neurons of the direct and indirect pathways are synaptically interconnected (Aronin et al., 1986; Yung et al., 1996). In D2R-/- mice, SP reduction might be dependent on the inhibition of striatonigral neurons by overactive striatopallidal collaterals. Blockade of A2ARs on these neurons, by restoring striatopallidal activity, reduces the inhibition on striatonigral neurons resulting in an increase and a normalization of SP expression in mutant mice. This might be the mechanism responsible for the upregulation of SP
mRNA expression in $\mathrm{D} 2 \mathrm{R}-/-$ mice, on administration of $\mathrm{KW}$ 6002. Alternatively, this effect might be mediated by cholinergic interneurons also expressing A2AR (Richardson et al., 2000). Indeed, A2AR antagonists reduce ACh release (Kurokawa et al., 1996), and the blockade of muscarinic receptors increases SP expression (Lucas and Harlan, 1995). Thus KW-6002 treatment might suppress ACh release in the striatum, and then the decreased ACh tone results in an increase of SP mRNA expression in the mutants. The locomotor stimulant effect of KW-6002 on WT animals seems to be higher than in the D2R-/- group, and a genotype-treatment interaction is revealed by the ANOVA analysis. However, this result might be dependent on the habituation of both groups of animals to the open field because the treatment was given when the animals were at rest. Thus, the basal activity of the WT group, as compared with the D2R group, might have been underestimated. Interestingly, a genotype-treatment interaction has not been found in the rotarod test. This test evaluates higher integration of motor function and body balance, such as combined movement of forelimbs and hindlimbs on the rod. We might speculate that the extent of the contribution of adenosine to some behavior as related to locomotor functions is different.

A balance of the direct and indirect pathways is required for the accomplishment of normal movements (Gerfen, 1992). Movement impairments in Parkinson's disease and in D2R-/- mice are the result of an imbalance in the activity of these pathways caused by the reduction of dopamine in the first case and of D2R-mediated signaling in the second. Behavioral studies on $\mathrm{D} 2 \mathrm{R}-/-$ mice treated with KW-6002 revealed that this selective A2AR antagonist is able to rescue the motor impairment observed in these mice. This suggests that blockade of $\mathrm{A} 2 \mathrm{~A}$ receptor might reduce the imbalance activity of striatal neurons. Importantly, adenosine KW6002 restores the movement impairment in mutant mice in the absence of D2 receptors, indicating that its activity is independent of D2-mediated mechanisms. In normal conditions, where the nigrostriatal projections and D2Rs functions are preserved, independent $A 2 A R$ and $D 2 R$ activities as well as A2AR/D2R intramembrane or intracellular interactions might occur in striatopallidal neurons. However, in conditions where dopamine or D2R activity is lowered or absent (e.g., in Parkinson's disease patients, MPTP-exposed monkeys, and D2R knockout mice), adenosine through A2AR may still elicits its proper physiological effects independently from the antagonistic interaction with dopaminemediated signaling. This has important relevance in developing novel therapies for Parkinson's disease.

In conclusion, our study shows that KW-6002 treatment of D2R $-/-$ mice reestablishes their altered striatal gene expression and locomotor behavior. Blockade of A2ARs might decrease the neuronal activity of the striatopallidal indirect pathway in the absence of D2R-mediated signaling. This strongly suggests that A2AR and D2R have antagonistic but independent functions in the striatum. These results also show that adenosine should be 
considered as one of the determinants in the control of striatal neuronal activities relevant to motor functions.

\section{REFERENCES}

Aronin N, Chase K, DiFiglia M (1986) Glutamic acid decarboxylase and enkephalin immunoreactive axon terminals in the rat neostriatum synapse with striatonigral neurons. Brain Res 365:151-158.

Augood SJ, Emson PC, Mitchell IJ, Boyce S, Clarke C, Crossman AR (1989) Cellular localization of enkephalin gene expression in MPTPtreated cynomolgus monkeys. Brain Res Mol Brain Res 6:85-92.

Baik JH, Picetti R, Saiardi A, Thiriet G, Dierich A, Depaulis A, Le Meur M, Borrelli E (1995) Parkinsonian-like locomotor impairment in mice lacking dopamine D2 receptors. Nature 377:424-428.

Boegman RJ, Vincent SR (1996) Involvement of adenosine and glutamate receptors in the induction of c-fos in the striatum by haloperidol. Synapse 22:70-77.

Chomczynski P, Sacchi N (1987) Single-step method of RNA isolation by acid guanidinium thiocyanate-phenol-chloroform extraction. Anal Biochem 162:156-159.

DeLong MR (1990) Primate models of movement disorders of basal ganglia origin. Trends Neurosci 13:281-285.

Ferré S, Rubio A, Fuxe K (1991a) Stimulation of adenosine A2 receptors induces catalepsy. Neurosci Lett 30:162-164.

Ferré S, von Euler G, Johansson B, Fredholm BB, Fuxe K (1991b) Stimulation of high-affinity adenosine A2 receptors decreases the affinity of dopamine D2 receptors in rat striatal membranes. Proc Natl Acad Sci USA 88:7238-7241.

Ferré S, Fuxe K, von Euler G, Johansson B, Fredholm BB (1992) Adenosine-dopamine interactions in the brain. Neuroscience 51:501-512.

Ferré S, Schwarcz R, Li XM, Snaprud P, Ogren SO, Fuxe K (1994) Chronic haloperidol treatment leads to an increase in the intramembrane interaction between adenosine $\mathrm{A} 2$ and dopamine $\mathrm{D} 2$ receptors in the neostriatum. Psychopharmacology (Berl) 116:279-284.

Ferré S, Fredholm BB, Morelli M, Popoli P, Fuxe K (1997) Adenosinedopamine receptor-receptor interactions as an integrative mechanism in the basal ganglia. Trends Neurosci 20:482-487.

Fink JS, Weaver DR, Rivkees SA, Peterfreund RA, Pollack AE, Adler EM, Reppert SM (1992) Molecular cloning of the rat A2 adenosine receptor: selective co-expression with D2 dopamine receptors in rat striatum. Brain Res Mol Brain Res 14:186-195.

Gerfen CR (1992) The neostriatal mosaic: multiple levels of compartmental organization. Trends Neurosci 15:133-139.

Gerfen CR, Engber TM, Mahan LC, Susel Z, Chase TN, Monsma Jr FJ, Sibley DR (1990) D1 and D2 dopamine receptor-regulated gene expression of striatonigral and striatopallidal neurons. Science 250:1429-1432.

Janssen PAJ, Jageneau AH, Schellekens KHL (1960) Chemistry and pharmacology of compounds related to 4-(4-hydroxy-4-phenyl-piperidino)butyrophenone. Part IV: Influence of haloperidol (R1625) and of chlorpromazine on the behaviour of rats in an unfamiliar "open field" situation. Psycopharmacologia 1:389-392.

Jarvis MF, Williams M (1989) Direct autoradiographic localization of adenosine A2 receptors in the rat brain using the A2-selective agonist, [3H]CGS 21680. Eur J Pharmacol 168:243-246.

Jung M-Y, Skryabin BV, Arai M, Abbondanzo S, Fu D, Brosius J, Robakis NK, Polites HG, Pintar JE, Schmauss C (1999) Potentiation of the D2 mutant motor phenotype in mice lacking dopamine D2 and D3 receptors. Neuroscience 91:911-924.

Kanda T, Tashiro T, Kuwana Y, Jenner P (1998) Adenosine A2A receptors modify motor function in MPTP-treated common marmosets. NeuroReport 24:2857-2860.

Kelly MA, Rubinstein M, Phillips TJ, Lessov CN, Burkhart-Kasch S, Zhang G, Bunzow JR, Fang Y, Gerhardt GA, Grandy KD, Low MJ (1998) Locomotor activity in D2 dopamine receptor- deficient mice is determined by gene dosage, genetic background, and developmental adaptations. J Neurosci 18:3470-3479.

Kurokawa M, Kirk IP, Kirkpatrick KA, Kase H, Richardson PJ (1994) Inhibition by KF17837 of adenosine A2A receptor-mediated modulation of striatal GABA and ACh release. Br J Pharmacol 113:43-48.

Kurokawa M, Koga K, Kase H, Nakamura J, Kuwana Y (1996) Adenosine A2a receptor-mediated modulation of striatal acetylcholine release in vivo. J Neurochem 66:1882-1888.

Ledent C, Vaugeois JM, Schiffmann SN, Pedrazzini T, El Yacoubi M,
Vanderhaeghen JJ, Costentin J, Heath JK, Vassart G, Parmentier M (1997) Aggressiveness, hypoalgesia and high blood pressure in mice lacking the adenosine A2a receptor. Nature 388:674-678.

Le Moine C, Normand E, Bloch B (1991) Phenotypical characterization of the rat striatal neurons expressing the D1 dopamine receptor gene. Proc Natl Acad Sci USA 88:4205-4209.

Lucas LR, Harlan RE (1995). Cholinergic regulation of tachykinin- and enkephalin-gene expression in the rat striatum. Brain Res Mol Brain Res 30:181-195.

Martinez-Mir MI, Probst A, Palacios JM (1991) Adenosine A2 receptors: selective localization in the human basal ganglia and alterations with disease. Neuroscience 42:697-706.

Morelli M, Fenu S, Pinna A, Di Chiara G (1994) Adenosine A2 receptors interact negatively with dopamine D1 and D2 receptors in unilaterally 6-hydroxydopamine-lesioned rats. Eur J Pharmacol 251:21-25.

Mori A, Shindou T, Ichimura M, Nonaka H, Kase H (1996) The role of adenosine A2a receptors in regulating GABAergic synaptic transmission in striatal medium spiny neurons. J Neurosci 16:605-611.

Munson PJ, Rodbard D (1980) LIGAND, a versatile computerized approach for characterization of ligand-binding systems. Anal Biochem 107:220-239.

Nikodijevic O, Sarges R, Daly JW, Jacobson KA (1991) Behavioral effects of A1- and A2-selective adenosine agonists and antagonists: evidence for synergism and antagonism. J Pharmacol Exp Ther 259:286-294.

Obeso JA, Rodriguez MC, DeLong MR (1997) Basal ganglia pathophysiology. A critical review. Adv Neurol 74:3-18.

Pertwee RG (1972) The ring test: a quantitative method for assessing the "cataleptic" effect of cannabis in mice. Br J Pharmacol 46:753-763.

Przedborski S, Levivier M, Jiang H, Ferreira M, Jackson-Lewis V, Donaldson D, Togasaki DM (1995) Dose-dependent lesions of the dopaminergic nigrostriatal pathway induced by intrastriatal injection of 6-hydroxydopamine. Neuroscience 67:631-647.

Richardson PJ, Kase H, Jenner P (1997) Adenosine A2A receptor antagonists as new agents for the treatment of Parkinson's disease. Trends Pharmacol Sci 18:338-344.

Richardson PJ, Dixon AK, Lee K, Bell MI, Cox PJ, Williams R, Pinnock RD, Freeman TC (2000) Correlating physiology with gene expression in striatal cholinergic neurones. J Neurochem 74:839-846.

Sambrook J, Fritsch EF, Maniatis T (1989) Molecular cloning: a laboratory manual, Ed 2. New York: Cold Spring Harbor Laboratory.

Schiffmann SN, Jacobs O, Vanderhaeghen JJ (1991) Striatal restricted adenosine A2 receptor (RDC8) is expressed by enkephalin but not by substance P neurons: an in situ hybridization histochemistry study. J Neurochem 57:1062-1067.

Shimada J, Koike N, Nonaka H, Shiozaki S, Yanagawa K, Kanda T, Kobayashi H, Ichimura M, Nakamura J, Kase H, Suzuki F (1997) (E)1,3-diethyl-8-(3,4,-trimethoxystyryl)-7-methylxanthine: a potent adenosine A2 antagonist with anti-cataleptic activity. Bioorg Med Chem Lett 7:2349-2352.

Shiozaki S, Ichikawa S, Nakamura J, Kitamura S, Yamada K, Kuwana Y (1999) Actions of adenosine A2A receptor antagonist KW-6002 on druginduced catalepsy and hypokinesia caused by reserpine or MPTP. Psychopharmacology (Berl) 147:90-95.

Snyder SH (1985) Adenosine as a neuromodulator. Annu Rev Neurosci 8:103-124.

Van Calker D, Muller M, Hamprecht B (1979) Adenosine regulates via two different types of receptors, the accumulation of cyclic AMP in cultured brain cells. J Neurochem 33:999-1005.

Wolffgramm J, Rommelspacher H, Buck E (1990) Ethanol reduces tolerance, sensitization, and up-regulation of D2-receptors after subchronic haloperidol. Pharmacol Biochem Behav 36:907-914.

Yang SN, Dasgupta S, Lledo PM, Vincent JD, Fuxe K (1995) Reduction of dopamine D2 receptor transduction by activation of adenosine A2a receptors in stably A2a/D2 (long-form) receptor co-transfected mouse fibroblast cell lines: studies on intracellular calcium levels. Neuroscience 68:729-736.

Yung KK, Smith AD, Levey AI, Bolam JP (1996) Synaptic connections between spiny neurons of the direct and indirect pathways in the neostriatum of the rat: evidence from dopamine receptor and neuropeptide immunostaining. Eur J Neurosci 8:861-869.

Zurawski G, Benedik M, Kamb BJ, Abrams JS, Zurawski SM, Lee FD (1986) Activation of mouse T-helper cells induces abundant preproenkephalin mRNA synthesis. Science 232:772-775. 